\title{
EFFECTIVENESS OF PHENOMENON BASED LEARNING (PHENOBL) MODEL APPLICATION FOR IMPROVING STUDENT LEARNING RESULTS IN OPTICAL MATERIALS
}

\author{
Tesa Liantika Putri ${ }^{* 1)}$ Azizahwati $^{2)}$ Nur Islami ${ }^{3)}$ \\ ${ }^{1,2,3)}$ Physics Education, University of Riau \\ e-mail: tesaliantikaputri@yahoo.co.id \\ azizafkip@gmail.com \\ nurislami@lecturer.unri.ac.id
}

\begin{abstract}
The learning process of physics at school, the topics is sometime less relatedto the existing dailylife phenomenon.This condition causes low improvement of students' cognitive learning result. In this case, it was a necessary to apply a learning model to improve student learning result by applying phenomenon based learning model (PhenoBL). Quasi experiment in the form of nonequivalent control group design as the model of the research. The instrument to collect data used test of student cognitive at pretest and posttest, respectively. The Data was analyzed by descriptive and inferential analysis. The results of descriptive analysis show the average absorption rate of experiment class is $71.05 \%$ and control class is $63.33 \%$ which both classes are in a good category. In the paired sample t-test results stated an increasing of students cognitive learning outcomes from pretest to posttest. This can also be seen from the inferential analysis in that means there was a significant differences between experimental class and kontrol class. Thus, it can be concluded that the use of PhenoBL model can improve student learning outcomes of class XI MIPA SMA Negeri 5 Pekanbaru on optical material.
\end{abstract}

Keywords: Cognitive learning outcomes, Optics, PhenoBL

\section{EFEKTIVITAS PENERAPAN MODEL PHENOMENON BASED LEARNING (PHENOBL) UNTUK MENINGKATKAN HASIL BELAJAR SISWA SMA PADA MATERI OPTIK}

\author{
Tesa Liantika Putri ${ }^{* 1)}$ Azizahwati $^{2)}$ Nur Islami ${ }^{3)}$ \\ ${ }^{1,2,3)}$ Physics Education, University of Riau
}

\begin{abstract}
Abstrak
Proses pembelajaran fisika di sekolah kurang mengaitkan materi pelajaran terhadap fenomena yang ada dalam kehidupan sehari-hari yang menyebabkan rendahnya hasil belajar kognitif siswa, dalam hal ini perlu diterapkan suatu model pembelajaran yang dapat meningkatkan hasil belajar siswa yaitu dengan penerapan model phenomenon based learning (PhenoBL). Jenis penelitian yang digunakan adalah kuasi eksperimen dengan rancangan nonequivalent control group design. Instrumen pengumpulan data menggunakan tes hasil belajar kognitif siswa yang terdiri dari pretest dan posttest, dianalisis menggunakan analisis deskriptif dan inferensial. Hasil analisis deskriptif diperoleh daya serap rata-rata kelas eksperimen 71,05\% dan kelas kontrol $63,33 \%$ dengan kategori pembelajaran baik dan cukup baik sedangkan hasil paired sample t-test menyatakan bahwa terjadinya peningkatan hasil belajar kognitif siswa dari pretest ke posttest. Hal ini juga dapat dilihat dari analisis inferensial dimana hasil independent-sample t-test kedua kelas terdapat perbedaan yang signifikan antara kelas eksperimen dan kelas kontrol. Dengan demikian dapat disimpulkan bahwa


penggunaan model PhenoBL dapat meningkatkan hasil belajar siswa kelas XI MIPA SMA Negeri 5 Pekanbaru pada materi optik.

Kata kunci: Hasil belajar kognitif, Optik, PhenoBL

\section{Pendahuluan}

Sistem pendidikan Indonesia terus mengalami kemajuan, ini dapat dilihat dari pergantian kurikulum KTSP 2006 menjadi kurikulum 2013 revisi 2016 (Depdiknas, 2006). Perubahan tersebut dilakukan dalam rangka peningkatan mutu pendidikan, maka perlu diadakan perubahan paradigma dalam menelaah proses belajar siswa dan interaksi antara siswa dan guru (Hopsah Nurpatmawati, et al., 2017)

Pada dasarnya dunia pendidikan pada saat ini menurut Suharsimi Arikunto, et al. (2016) menjuru kepada siswa yang dituntut agar lebih aktif, kreatif dan inovatif dalam memahami materi pelajaran seperti pelajaran fisika yang merupakan satu ilmu pengetahuan alam dasar yang banyak digunakan sebagai dasar bagi ilmu-ilmu yang lain dan merupakan ilmu pengetahuan yang mempelajari sifat dan gejala pada benda-benda di alam serta banyak diaplikasikan dalam kehidupan sehari-hari.

Fisika sebagai produk yang berarti bahwa fisika merupakan kumpulan pengetahuan yang berupa fakta, konsep, prinsip, hukum dan rumus sedangkan fisika dipandang sebagai proses sangat berkaitan dengan fenomena, pengukuran, pengamatan dan penyelidikan (Eka Norbaizura, et al., 2017). Akan tetapi pembelajaran fisika di sekolah sangat teoritik dan tidak mengaitkan dengan fenomena fisika yang ada di lingkungan seperti materi pelajaran optik.

Ketika pembelajaran materi optik sangat sulit dipahami siswa karena bersifat abstrak, banyak rumus dan juga guru bidang studi tidak mengaitkan pelajaran fisika dengan fenomenafenomena yang terjadi dalam kehidupan sehari-hari serta pengaplikasian alat-alat laboratorium tidak sering dimanfaatkan dalam proses belajar mengajar sehingga pembelajaran hanya berfokus pada penggunaan metode ceramah. Hal ini menyebabkan penguasan kognitif fisika yang diharapkan tidak tercapai secara maksimal.
Mundilarto (2010) menyatakan bahwa secara umum, rendahnya rata-rata perolehan nilai pada mata pelajaran fisika mengindikasi kan proses pembelajaran belum dapat berlangsung sebagaimana mestinya. Kondisi tersebut menurut Lasma Br Hotang (2010) disebabkan karena pembelajaran fisika selama ini lebih sering disampaikan guru kepada siswa sebagai fakta, bukan sebagai peristiwa atau fenomena yang harus diamati, diukur dan di diskusikan sehingga ini menuntut siswa agar dapat mengingat berbagai konsep dan rumus tanpa dituntut untuk menghubungkannya dengan kehidupan sehari-hari. Delta Apriani, et al. (2017) mengatakan bahwa dalam proses pembelajaran guru harus memiliki strategi pembelajaran yang tepat guna meningkatkan aktivitas dan meningkatkan hasil belajar siswa

Bertitik tolak dari permasalahan yang telah diuraikan di atas, maka perlu diupayakan penerapan suatu model pembelajaran yang dapat menarik minat siswa dalam pembelajaran fisika sekaligus meningkatkan hasil belajar siswa pada ranah kognitif. Ini juga dipengaruhi dengan pemilihan model pembelajaran yang tepat akan mempermudah proses terbentuknya pengetahuan kepada siswa (Futri Hidayatullahet al., 2017).

Salah satu model pembelajaran yang dapat diterapkan adalah model Phenomenon Based Learning (PhenoBL). Ita Khanasta, et al. (2016) mengatakan bahwa model PhenoBL didasari pada materi pelajaran yang dihubungkan dengan kejadian atau fenomena fisika yang terjadi ataupun telah ada dalam kehidupan sehari-hari. Fenomena dalam model PhenoBL yang dimaksud adalah gejala atau peristiwa yang dijumpai siswa dalam kesehariannya, baik yang terjadi di alam maupun dalam penggunaan alat-alat laboratorium yang digunakan untuk melihat fenomena optik.

Penggunaan model PhenoBL dapat memberikan daya tarik bagi siswa dalam mempelajari materi optik walaupun materi tersebut bersifat abstrak akan tetapi materi tersebut banyak diaplikasikan dalam 
kehidupan sehari-hari seperti penggunaan lensa kacamata, penggunaan teropong untuk melihat sesuatu yang jauh, mikroskop ataupun kaca pembesar. Langkah yang paling umum digunakan dalam model PhenoBL adalah mengorientasi siswa pada sebuah fenomena nyata yang berkaitan dengan materi pelajaran, pengorganisasian kelompok belajar, penyelidi kan individu atau kelompok, menyajikan hasil penyelidikan fenomena dan menganalisis dan mengevaluasi fenomena (Vasileios \& Johanna, 2016).

Berdasarkan uraian latar belakang yang telah dijelaskan maka penulis tertarik untuk mengadakan penelitian tentang efektivitas penerapan model phenomenon based learning (phenobl)untuk meningkatkan hasil belajar siswa SMA pada materi optik. Hasil penelitian ini dapat dijadikan sebagai salah satu alternatif strategi pembelajaran fisika yang dapat diterapkan untuk meningkatkan hasil belajar fisika siswa dan juga cara meningkatkan kecerdasan siswa melalui kegiatan yang berorientasi pada kehidupan sehari-hari.

\section{Bahan dan Metode}

Penelitian dilakukan di SMA Negeri 5 Pekanbaru pada kelas XI yang terdiri dari 35 orang kelas eksperimen dan 35 orang kelas kontrol. Waktu penelitian dilakukan pada semester genap tahun ajaran 2017/2018. Jumlah populasi penelitian adalah 188 orang siswa kelas XI MIPA.

Jenis penelitian yang dilakukan adalah penelitian quasi experimental design. Rancangan yang digunakan pada penelitian ini adalah nonequivalent control group design (Sugiyono, 2017). Pada rancangan ini sampel diambil dari populasi kemudian yang dikelompokkan menjadi dua yaitu kelompok eksperimen dan kelompok kontrol. Kelas eksperimen akan diterapkan model phenomenon based learning, sedangkan kelas kontrol diterapkan pembelajaran konvensional. Kemudian dilanjutkan dengan pemberian pretest dan posttest kepada kelas eksperimen dan kelas kontrol.

Instrumen yang digunakan untuk mengumpulkan data pada penelitian ini adalah tes hasil belajar kognitif siswa pada materi optik sebagai pretest dan posttest yang terdiri dari 15 soal pilihan berganda dan telah di validasi. Hasil yang diperoleh dari tes hasil belajar kognitif akan dianalisis menggunakan teknik analisis deskriptif dan analisis inferensial. Pada teknik analisis deskriptif data yang didapat dianalisis untuk melihat gambaran hasil belajar kognitif siswa dengan menggunakan kriteria daya serap dan efektivitas pembelajaran yang dapat dilihat pada Tabel 1.

Tabel 1. Ketegori daya serap

\begin{tabular}{cc}
\hline Interval (\%) & Kategori Daya Serap \\
\hline $85-100$ & Amat Baik \\
$70-84$ & Baik \\
$50-69$ & Cukup Baik \\
$0-49$ & Kurang Baik \\
\hline
\end{tabular}

Sumber: Depdiknas (2006)

Tabel 2. Ketegori efektivitas pembelajaran

\begin{tabular}{cc}
\hline $\begin{array}{c}\text { Interval } \\
(\%)\end{array}$ & $\begin{array}{c}\text { Kategori Efektivitas } \\
\text { Pembelajaran }\end{array}$ \\
\hline $85-100$ & Sangat Efektif \\
$70-84$ & Efektif \\
$50-69$ & Cukup efektif \\
$0-49$ & Kurang efektif \\
\hline
\end{tabular}

Sumber: Depdiknas (2006).

Analisis inferensial dilakukan untuk mengetahui perbedaan hasil belajar kognitif siswa setelah diterapkan model PhenoBL pada kelas eksperimen dan diterapkan pembelajaran konvensional pada kelas kontrol melalui uji hipotesis yang berlaku untuk populasi. Sebelum melakukan uji hipotesis terlebih dahulu dilakukan uji prasyarat yaitu uji normalitas dan uji homogenitas. Data yang digunakan untuk uji normal dan homogen adalah data pretest sebelum diberikan treatment pembelajaran dan data posttest setelah pembelajaran. Apabila data yang diperoleh berdistribusi normal dan homogen selanjutnya dilakukan uji hipotesis untuk data pretest dan data posttest dengan kriteria pengambilan kesimpulan yaitu :

1) Jika signifikan, $p \geq 0,05$ maka $H_{o}$ diterima maknanya tidak terdapat perbedaan yang signifikan antara kelas eksperimen dan kelas kontrol.

2) Jika signifikan, $p<0,05$ maka $H_{o}$ ditolak maknanya terdapat perbedaan yang signifikan antara kelas eksperimen dan kelas kontrol. 


\section{Hasil dan Pembahasan}

Penelitian tentang efektivitas penerapan model phenomenon based learning (PhenoBL) untuk meningkatkan hasil belajar siswa SMA pada materi optik telah dilaksanakan di SMA Negeri 5 Pekanbaru adapun hasil penelitian dapat dilihat pada Tabel 3 dan Tabel 4.

Tabel 3. Daya serap rata-rata eksperimen

\begin{tabular}{ccccc}
\hline No & $\begin{array}{c}\text { Interval } \\
(\%)\end{array}$ & Kategori & $\begin{array}{c}\text { Kelas Eksperimen } \\
\text { Jumlah } \\
\text { siswa }\end{array}$ \\
\hline 1 & $85-100$ & Amat Baik & 20 & 7 \\
2 & $70-84$ & Baik & 31,43 & 11 \\
3 & $50-69$ & Cukup Baik & 45,72 & 16 \\
4 & $0-49$ & Kurang Baik & 2,85 & 1 \\
\hline Rata-rata & & \multicolumn{2}{c}{71,05} \\
\hline Kategori & & \multicolumn{2}{c}{ Baik } \\
\hline
\end{tabular}

Tabel 4. Daya serap rata-rata eksperimen

\begin{tabular}{|c|c|c|c|c|}
\hline \multirow[b]{2}{*}{ No } & \multirow[b]{2}{*}{$\begin{array}{c}\text { Interval } \\
(\%)\end{array}$} & \multirow[b]{2}{*}{ Kategori } & \multicolumn{2}{|c|}{ Kelas Kontrol } \\
\hline & & & $\%$ & $\begin{array}{c}\text { Jumlah } \\
\text { siswa }\end{array}$ \\
\hline 1 & $85-100$ & Amat Baik & 2,85 & 1 \\
\hline 2 & $70-84$ & Baik & 14,29 & 5 \\
\hline 3 & $50-69$ & Cukup Baik & 68,57 & 24 \\
\hline 4 & $0-49$ & Kurang Baik & 14,29 & 5 \\
\hline \multicolumn{2}{|c|}{ Rata-rata } & & \multicolumn{2}{|c|}{61,33} \\
\hline \multicolumn{2}{|c|}{ Kategori } & & \multicolumn{2}{|c|}{ Cukup baik } \\
\hline
\end{tabular}

Berdasarkan Tabel 3 dan Tabel 4 daya serap rata-rata setelah dilakukan posttest untuk kelas eksperimen dan kelas kontrol terdapat perbedaan dengan rentang nilai kedua kelas sebesar 9,72\%. Keempat kategori dari Tabel 3 dan Tabel 4 menyatakan jumlah siswa yang mendapatkan kategori daya serap amat baik, baik, cukup baik dan kurang baik. Persentase siswa dari kelas eksperimen banyak mendapatkan kategori cukup baik dengan jumlah siswa 16 orang dari 35 orang siswa yang ada sedangkan pada kelas kontrol kebanyakan siswa juga berada pada kategori cukup baik dengan jumlah siswa 24 orang dari 35 orang.

Terjadinya perbedaan hasil belajar kognitif antara kedua kelas dipengaruhi oleh penggunaan model PhenoBL yang dapat meningkatkan motivasi siswa dalam belajar, ini juga sesuai dengan pendapat Sartika Noviyanti, et al. (2017) yang mengatakan bahwa motivasi adalah faktor yang sangat penting serta dapat menumbuhkan semangat belajar siswa, dimana pada model PhenoBL siswa dituntut lebih aktif dalam melakukan pengamatan-pengamatan dari kegiatan seharihari ataupun menghubungkan pembelajaran fisika dengan fenomena atau kejadian alam yang terjadi seperti terbentuknya pelangi yang sesuai dengan konsep pembiasan cahaya yang ada pada materi optik yang dapat dijadikan sebagai motivasi belajar siswa.

Hal ini didukung oleh penelitian yang dilakukan oleh Ita Khanasta, et al. (2016) yang menyatakan bahwa model pembelajaran PhenoBL dapat mengkondisikan siswa mengamati fenomena yang terjadi secara langsung melalui kegiatan praktikum ataupun demonstrasi yang dilakukan oleh guru sehingga siswa dapat lebih mengingat informasi-informasi yang diperoleh dari fenomena tersebut dan dapat memberikan suatu pembelajaran yang lebih bermakna bagi siswa.

Minarty Pareken, et al. (2015) juga menyatakan bahwa model PhenoBL dapat menarik minta belajar siswa karena pada model ini siswa dituntut untuk menemukan konsep fisika melalui masalah yang diberikan oleh guru dari fenomena yang sering dijumpai siswa dalam kehidupan sehari-hari, berupa permasalahan atau pertanyaan-pertanyaan yang sifatnya membimbing, atau berupa penjelasan singkat sehubungan dengan materi, sehingga siswa merasa tertarik untuk mengetahui permasalahan fisika dalam kehidupan sehari-hari, baik berupa proses, sebab-akibat, gejala maupun hasil yang ditimbulkan oleh fenomena tersebut sehingga dapat meningkatkan hasil belajar siswa.

Pada penelitian ini masih ada satu orang siswa yang mendapatkan kategori daya serap kurang baik dengan persentase sebesar 26,67 $\%$ pada kelas ekperimen, hal ini dikarenakan pada beberapa indikator pembahasan materi pemantulan, pembiasan dan alat-alat optik, siswa tersebut tidak dapat menggunakan rumus yang tepat sesuai pertannyaan dari soal, keliru dalam penggunaan tanda positif ataupun negatif, cara melukiskan sinar-sinar istimewa pada cermin dan lensa serta konsep fisika pada pengaplikasian alat-alat optik dalam kehidupan sehari-hari tidak dapat dijelaskan dengan baik dan benar.

Permasalahan yang dialami siswa tersebut dapat disebabkan karena siswa tidak 
memperhatikan persentasi kelompok, tidak aktif dalam berdiskusi kelompok, tidak mengamati fenomena yang telah di praktikum kan dengan sungguh-sungguh, keliru dalam menjawab soal, tidak memperhatikan tanda positif dan negatif pada soal serta penganalisaan soal sangat kurang, sehingga menyebabkan rendahnya perolehan nilai yang didapatkan.

Mentari Darma Putri \& Dadi Rusdiana (2017) mengatakan bahwa dengan terjadinya diskusi argumentasi yang baik dalam proses pembelajaran maka akan tercipta ide-ide baru, merubah konsep pemikiran siswa terhadap pelajaran fisika serta membentuk pola pikir yang lebih ilmiah, sehingga dapat menunjang keberhasilan indikator pembelajaran.

Keberhasilan siswa dalam mengerjakan tes ujian juga dipengaruhi oleh cara seorang guru menyampaikan dan menguasai kelas pada saat pembelajaran berlangsung. Menurut Nursani Saragih, et al. (2017) keberhasilan pencapaian indikator didorong dengan pemberian motivasi yang mengacu pada materi pembelajaran, seperti halnya penggunaan model PhenoBL ini. Pada model ini motivasi yang diberikan lebih bersifat nyata dan dapat dilihat secara langsung oleh siswa serta dapat mengaitknnya dengan fenomena optik fisika yang terjadi dalam kegiatan sehari-hari siswa tersebut, sehingga dapat memberikan semangat dalam belajar dan memberikan gambaran efektivitas pembelajaran yang terjadi selama proses belajar.

Hasil efektivitas yang diperoleh dari penelitian pada kelas eksperimen adalah 71,05 sedangkan kelas kontrol adalah 61,33 maka dari itu efektivitas pembelajaran yang diperoleh kedua kelas adalah efektif dan cukup baik. Sehingga penggunaan model PhenoBL memberikan peningkatan hasil belajar.

Pada analisis inferensial dilakukan uji normalitas dan uji hipotesis. Hasil uji normalitas data pretest dapat dilihat pada Tabel 5.

Tabel 5. Uji normalitas data pretest

\begin{tabular}{|c|c|c|}
\hline \multirow[t]{2}{*}{ Kelas } & \multicolumn{2}{|c|}{ Kolmogorov Smirnov } \\
\hline & $\mathrm{df}$ & Sig. \\
\hline Kelas Eksperimen & 35 & .175 \\
\hline Kelas Kontrol & 35 & .069 \\
\hline
\end{tabular}

Tabel 5 menunjukkan output dari normalitas kelas eksperiemn dan kontrol yang diperoleh nilai $(p>0,05)$ untuk kelas eksperimen dan $(p>0,05)$ untuk kelas kontrol yang artinya data dari pretest berdistribusi nomal. Berdasarkan hasil output dari independent sample t-test diperoleh $\mathrm{F}=2.087$, $p=0,153(p>0,05)$ pada Levenes's Test for Equality of Variances yang menyatakan nilai homogenitas kedua kelas dimana hasil pretest optik yang telah diujiankan kepada kelas eksperimen dan kelas kontrol memiliki varians yang sama atau homogen. Syarat untuk menerapkan model ataupun strategi mengguna kan dua kelas sebagai kelas penelitian, data sampelnya harus memiliki varians yang sama atau kedua kelas homogen.

Pengujian hipotesis dapat dilihat dari output independent sample t-test dari hasil ujian pretest yang telah dilakukan. Pengujian hipotesis ini bertujuan untuk mengetahui apakah tidak terdapat perbedaan yang signifikan antar kelas eksperimen dan kelas kontrol. Uji t yang dilakukan adalah untuk menguji hipotesis $\mathrm{H}_{\mathrm{o}}$ dimana pada hasil pretest, output independent-sample t-test kedua kelas diperoleh $\mathrm{t}=68$, signifikansi $p=$ $0,773(p>0,05)$ hasil ini menunjukkan bahwa $\mathrm{H}_{\mathrm{o}}$ diterima. Oleh karena itu kesimpulan dari data pretest yang didapatkan adalah tidak terdapat perbedaan yang signifikan sebelum diberikan treatment pembelajaran terhadap peningkatan hasil belajar kognitif siswa.

Ketika pembelajaran menggunakan model PhenoBL dan pembelajaran konvensional selesai, kelas eksperimen dan kelas kontrol akan diberikan posttest dengan soal yang sama seperti soal pretest, hanya saja pengurutan soalnya diacak. Hasil dari posttest akan dianalisis menggunakan analisis inferensial dengan melakukan independent sample t-test.

Hasil homogenitas kedua kelas dapat dilihat langsung pada output independent sample t-test (levenes's test for equality of variances dari uji homogeneity of variances) dengan nilai signifikansi $\mathrm{F}=2.015, p=0,160$ $(p>0,05)$ yang artinya data posttest kelas eksperimen dan kelas kontrol memiliki varians yang sama atau homogen.

Pengujian hipotesis bertujuan untuk mengetahui apakah terdapat perbedaan yang signifikan antara kelas eksperimen dengan kelas kontrol setelah pembelajaran. Uji t yang 
dilakukan adalah untuk menguji hipotesis $\mathrm{H}_{\mathrm{o}}$ dimana pada hasil posttest, output dari independent-sample t-test kedua kelas diperoleh $\mathrm{t}=3,572$, signifikansi $p=0,001(\mathrm{P}<$ $0,05)$ sehingga $\mathrm{H}_{\mathrm{o}}$ ditolak yang artinya terdapat perbedaan yang signifikan antara pembelajaran fisika melalui model phenomenon based learning dengan pembelajaran konvensional pada materi optik terhadap hasil belajar kognitif siswa serta jika dilihat hasil output paired sample t-test untuk kelas eksperimen $p$ $=0,000(p<0,05)$ dan kelas kontrol $p=0,000$ $(p<0,05)$ yang artinya terjadinya peningkatan hasil belajar siswa sebelum dan sesudah pembelajaran menggunakan model PhenoBL dan pembelajaran konvensional.

\section{Kesimpulan dan Saran}

Berdasarkan hasil penelitian yang telah dilakukan penggunaan model PhenoBL dapat meningkatkan hasil belajar siswa karena pengaplikasian model ini banyak terdapat dalam kehidupan sehari-hari yang membantu siswa dalam memahami konsep fisika secara nyata. Terdapat perbedaan yang signifikan hasil belajar siswa antara kelas yang menggunakan model pembelajaran PhenoBL dengan kelas konvensional.

Implementasi model phenomenon based learning dapat digunakan pada materi pokok yang berbeda dan jenjang pendidikan yang berbeda untuk meningkatkan mutu pendidikan dimasa yang akan datang serta untuk merubah pola pembelajaran yang konvensional ke pola pembelajaran yang lebih kreatif.

\section{Daftar Pustaka}

Delta Apriani, Azhar, \& Nur Islami, 2017. Hasil Belajar Kognitif Ipa Fisika Melalui Penerapan Model Pembelajaran Kooperatif Bermain Jawaban Pada Materi Pemuaian di Sekolah Menengah Pertama. Jurnal Online Mahasiswa (JOM) Bidang Keguruan dan Ilmu Pendidikan, 4 (1), 1-9.

Depdiknas, 2006. Model Kurikulum Tingkat Satuan Pendidikan untuk SMA. Direkrat Jendral Pendidikan Dasar dan Menengah, Jakarta.
Eka Norbaizura, Nur Islami, \& Mitri Irianti, 2016. Hasil Belajar Kognitif IPA Fisika Siswa dalam Pembelajaran Kooperatif Formasi Regu Tembak di SMP Negeri 34 Pekanbaru. Jurnal Online Mahasiswa (JOM) Bidang Keguruan dan Ilmu Pendidikan, 3(2), 1-11.

Futri Hidayatullah, Nur Islami, \& Mitri Irianti, 2017. Hasil Belajar Kognitif Ipa Fisika Siswa Melalui Penerapan Model Pembelajaran Kooperatif Tipe Talking Chips di Kelas VIII MTS Daarun Nahdhah Tawalib Bangkinang Kampar. Jurnal Online Mahasiswa (JOM) Bidang Keguruan dan Ilmu Pendidikan, 4 (1), 1-10.

Hopsah Nurpatmawati, Nur Islami, \& Fakhruddin, 2017. Analisis Perubahan Tingkat Konsepsi Sains Fisika Siswa Menggunakan Model Pembelajaran Poe (Predict-Observe-Explain) Pada Materi Momentum Dan Impuls Kelas X MAN 1 Pekanbaru. Jurnal Online Mahasiswa (JOM) Bidang Keguruan dan Ilmu Pendidikan, 4 (2), 1-9.

Ita Khanasta, Iriwi L.S. Sinon, \& Sri Wahyu Widyaningsih, 2016. Penerapan Model Pembelajaran Berbasis Fenomena Menggunakan Metode Demonstrasi Terhadap Berpikir Kritis Peserta Didik Kelas XI IPA SMA Yapis Manokwari. Wahana Didaktika, 14 (3), 14-27.

Lasma Br Hotang, Dadi Rusdiana, \& Ida Hamidah, 2010. Pembelajaran Berbasis Fenomena Pada Materi Kalor untuk Meningkatkan Pemahaman Konsep Siswa SMP. Prosiding Seminar Nasional Fisika,11-12 Mei 2010. Himpunan Fisika Indonesia Cabang Jawa Barat, pp. 394-402.

Mentari Darma Putri \& Dadi Rusdiana, 2017. Improving Scientific Argumentation Skills of Junior High School Students In Science Learning By Employing Phenomenon-Based Learning With Video Assistance Through A Modified "Flipped Classroom" Approach. Proceedings of ADVED2017-3rd International Conference on Advances in Education and Social Sciences, 9-11 Oktober 2017. Turkey, pp. 278-286.

Minarty Pareken, A.J. Patandean, \& Pariabti Palloan, 2015. Penerapan Model Pembelajaran Berbasis Fenomena 
Terhadap Keterampilan Berpikir Kritis dan Hasil Belajar Fisika Peserta Didik Kelas X SMA Negeri 2 Rantepao Kabupaten Toraja Utara. Jurnal Sains dan Pendidikan Fisika, 11(3), 214 - 221.

Mundilarto, 2010. Penilaian Hasil Belajar Fisika. P2IS UNY, Yogyakarta.

Nursani Saragih, Nur Islami, \& Muhammad Nasir, 2017. Penerapan Penerapan Metode Pembelajaran Pictorial Riddle Terhadap Motivasi Belajar Ipa Fisika Siswa Kelas VIII SMP Beer Seba Pekanbaru. Jurnal Online Mahasiswa (JOM) Bidang Keguruan dan Ilmu Pendidikan, 4(1), 1-8.
Sartika Noviyanti, Nur Islami, \& Muhammad Nasir, 2017. Hubungan Motivasi Belajar dan Self-Regulated Learning dengan Hasil Belajar Fisika Siswa Kelas XISMA Negeri 4 Pekanbaru Tahun Pelajaran 2016/ 2017. Jurnal Online Mahasiswa (JOM) Bidang Keguruan dan Ilmu Pendidikan, 4 (2),1-13.

Sugiyono, 2017. Metode Penelitian Kuantitatif Kualitatif dan $R \& D$. Alfabeta, Bandung.

Suharsimi Arikunto, 2016. Penelitian Tindakan Kelas. Bumi Aksara, Jakarta.

Vasileios Symeonidis \& Johanna F. Schwarz, 2016. Phenomenon-Based Teaching and Learning through the Pedagogical Lenses of Phenomenology: The Recent Curriculum Reform in Finland. Forum Oświatowe, 28 (2), 31-37. 